\title{
Effect of Coronavirus on Aquaculture in Oyo state, Nigeria
}

\author{
Selorm Omega ${ }^{1}$, Alexander T. K. Nuer ${ }^{1} \&$ Enoch Ametepey ${ }^{1}$ \\ ${ }^{1}$ Department of Agriculture Economics and Extension, University of Cape Coast, Ghana \\ Correspondence: Selorm Omega, Department of Agriculture Economics and Extension, University of Cape \\ Coast, Cape Coast, Ghana. Tel: 233-545-022-814. E-mail: selorm.omega@stu.ucc.edu.gh
}

Received: September 8, 2021

Accepted: October 5, $2021 \quad$ Online Published: October 15, 2021

doi:10.5539/jas.v13n11p153

URL: https://doi.org/10.5539/jas.v13n11p153

\begin{abstract}
Coronavirus 2019 is a global health concern that has left most countries in a state of severe economic meltdown. Scientific research has been down on the virus and its impact on various sectors but that of the Nigerian aquaculture industry has been missing. This paves the way for this research to aim at bridging this gap by looking at the perception of fish farmers on the influence of coronavirus on their activities, the challenges they face during the period of the virus, and the coping strategies adopted to mitigate the impact of the virus. The research used cross sectional survey design with the sample size being 11 fish farmers living in Oyo state, Nigeria. Homogeneous purposive sampling was used and primary data collected through the use of google form. The data collected was analysis using SPSS version 25.0. The result of the analysed data showed that: on socioeconomic characteristics; the majority of the respondent reported that Coronavirus has had an effect on their fishing activity and they were mostly small scale farmers with catfish being the predominate fish farmed. The majority of fish farmers perceived demand decline, high cost of production, fish being more expensive, and reduction of manpower on the farm due to lockdown measures. Reduction in walk-in customers to the farm was revealed as the major challenge posed by the pandemic, while the inability to get technical support as least. On coping strategies adopted, it was revealed that farmers have resorted to the development of their own feed.
\end{abstract}

Keywords: effect, Coronavirus, aquaculture, Nigeria

\section{Introduction}

The novel Coronavirus disease (COVID-19) from the family coronaviridae (subfamily Orthocoronavirinae), a single-stranded RNA virus measuring 80 to $120 \mathrm{~nm}$ in diameter is broadly distributed in mammals (Sharma et al., 2020). The virus was first reported in December 2019 in Wuhan, China (Wu et al., 2020). It was declared a public health emergency of international concern on 30 January 2020, and as a pandemic on 11 March 2020 by World Health Organisation. The virus primarily spread through close contact and small droplets produced when infected patients cough, sneeze, or talk (World Health Organisation, 2020; Chinese Center for Disease Control and Prevention, 2020). The virus has spread to 110 countries, with an estimated 11 million people infected as of 2 June 2020. Africa recorded its first case on 14 February 2020 in Egypt and Nigeria on the 27 February 2020 (Gilbert \& Gubar, 2020). The advent of the virus has led to a global health crisis, which has disrupted the economic system, security, and health of many countries. As some countries try to return to normality, the full economic impact of the virus is yet to be ascertained.

Aquaculture is a fast-growing agro-industrial activity with the potential to outpace population growth (Van der Merwe, 2015). The sector production has expanded by 12 times at an annual average of $8.8 \%$ (FAO, 2009). In 2012, FAO estimated that the total production of farmed fish stood at $\$ 119$ billion from the over 300 farmed fish species worldwide. The world distribution of aquaculture shows that Asia, mainly China, contributes about $90 \%$ of the total aquaculture production output, with only $1 \%$ from Africa. In Nigeria, aquaculture has been considered as an alternative to the declining capture fisheries, accounting for 85,000 metric tons in 2010 (Akinrotimi, Abu, \& Aranyo, 2011), and with demand for its output growing with increasing population.

Although COVID-19 does not directly affect fishes. It has however an indirect impact on the aquaculture sector through altering demand and supply patterns, logistical problem, reduction in the level of livelihood of fish farmers, and the serious health and food security consequence for people who depend on fish for their animal protein and essential micronutrients (Grema et al., 2020). COVID-19 which emerged from China, the major fish producer in the world will be the most hard-hit, hence all countries it export fish product to including Nigeria. In 
Nigeria, It is expected that on the supply side, the country will be hurt by the shortage of labour that will because due to lockdown restriction. Access to input and output market is also expected to be hindered by the restriction on movement and also the loss of food resulting from the disruption of the aquaculture value chain. Whiles, on the demand side, it is expected that demand for aquaculture products which is generally inelastic will cause price hikes. The resulting impact will be the shift of fish consumers to other protein products like beans, eggs, and meat.

Most literature on COVID-19 has paid attention to the socioeconomic, and economic impact of COVID-19 at the expense of the impact of COVID-19 on aquaculture in Africa and the world. This paper further contributes to our understanding on real effects COVID-19 has placed on aquaculture farmers and pathways that could help to mitigate such effects in foreseeable future.

\subsection{Research Objectives}

Hence, this research will seek to:

(1) identify the socioeconomic characteristics of fish farmers in Nigeria;

(2) examine the perception of fish farmers on the influence of COVID-19 on aquaculture;

(3) identify challenges faced by fish farmers during COVID-19, and;

(4) coping strategies adopted to mitigate the impact of COVID-19 on Nigeria aquaculture.

\subsection{Research Hypothesis}

$\mathrm{H}_{0}$ : There is no significant relationship between the socioeconomic characteristics of the respondent.

$\mathrm{H}_{1}$ : The paired challenges faced by farmers during COVID-19 are not different.

\section{Literature Review}

\subsection{Aquaculture}

Aquaculture, which is farming of seaweeds, crustaceans, bivalves, and fish, is a fast-growing sector of the food production industry in most economies around the world (Cai \& Leung, 2017). The rapid growth has been captured to be between 10- 15\% over the last decade (Brugère et al., 2019). Pauly and Zeller (2017) reported that aquaculture growth between 1996 and 2001 saw a 10.8million tons increase in production. The rapid growth of the sector according to Cisneros-Montemayor and Vincent (2016) is due to the growing population of the world, and the increasing demand for fish and fish products. The traditional catch system has failed to meet the growing demand, hence the improved growth of aquaculture. The growth pattern reported by Pauly and Zeller (2017) revealed that aquaculture was fast growing among developing countries at a rate of $10 \%$ as against $3.7 \%$ of developed countries.

In Nigeria, aquaculture after a series of failed attempts, has gain ground as the country moves to meet its projected annual 1.5 million tons of fish demand. Aquaculture accounted for 43,950 tons in 2004 of the total fish production of the country (Eriegha \& Ekokotu, 2017). This has led to the realization of aquaculture as a potential to diversifying farmer livelihood and income. The system of aquaculture production practiced in the country uses mostly earthen ponds, while ponds, raceways, and tanks are also gradually gaining popularity. Urban and peri-urban areas of the country due to the scarcity of land and growing problem of urbanization have led to the development and usage of recirculatory aquaculture systems (Haldén, Lindberg, \& Masembe, 2014). Small scale fish farms account for $70 \%$ of fish produce under aquaculture as the small scale farms vary from commercial subsistence to non-commercial subsistence farming (Kawarazuka, 2010). The most farmed fish species in Nigeria are the North African catfish, African bony tongue, and Nile Tilapia by small scale; O. niloticus, C. gariepinus, and H. bidorsalis by medium scale. Large scale combines the small scale and medium farmed fish with Gymnarchus, Atlanticus, Heterobranchus spp., Hybrid catfish, common carp, Aba, Flathead mullet among others.

\subsection{Challenges Faced by Aquaculture Sector in Nigeria}

Nigeria with its estimated 1.75 million hectares of suitable sites for the development of aquaculture is still far from achieving its full potential (Adewumi, 2015). A sector that was developed with the hope of making the country self-sufficient in its fish production, base on its high reliability in return on investment and low capital intensity relative to catch fisheries, is yet to be felt (Nchuchuwe \& Adejuwon, 2012). The sector as it currently stands is under developed despite it being a large source of livelihood to fish farmers and people that derive their livelihoods in coastal areas of the country. Aquaculture's contribution to the total fish production in Nigeria is insignificant. Adeoye and Elegunde (2012) attributed this to the monoculture (farming only catfish) nature of the 
Nigerian aquaculture sector. Therefore, the challenges of catfish tend to hinder the production capacity and aquaculture development of the country. The country has to find ways to overcome its annual 1.5 million tons of fish deficit. According to Morgan et al. (2017), the disruption of the production process has led to a large time of farms failing to attain profitability status. These disruptions in the production process may come as a result of the delay in the delivery of fish seeds, fingerlings, and even products like feed, and among others. Financial risk situation of farming makes loan acquisition difficult for farmers, forcing them to restore to small scale production. The lack of adequate technology and technical knowledge in fish farming production are some of the initial challenges fish farmers face. The genesis of these problems is the result of poor government policies toward the sector.

Secondly, Land which is the paramount resource to the start of fish farms is readily available. Though readily available, the land acquisition systems variation of the country varies and these lands sometimes are litigated (Adeogun et al., 2007). The location of the land also determines how the land will be used and the type of fish farming to be adopted by a farmer. Farmers who stay along swampy areas are more likely to adopt earthen ponds. According to Famakinwa et al. (2017), land availability for fish farming is entangled with variables such as population, the land tenure system, development of the country, and level of technology. Therefore, as population increases, land for agriculture are traded off for accommodation, meaning that the number of fish ponds will have to be limited to fit the land area. Land tenure systems ownership and rights, other than that which is based on outright purchase by a farmer or investor, will imply that after a farmer's leases or rent is over, the farmer will have to sell the ponds or destroy them. This is so because the land reverts to the owner per the status under which it was acquired by the farmer or investor. This in most cases, makes the use of earthen pond difficult as most rented and leased lands use plastic tanks to cultivate and produce fishes for targeted markets in Nigeria.

Furthermore water, which is the home and backbone of the aquaculture system is overly polluted by mining activities and industrial waste. Olowosegun et al. (2005) and Omitoyin and Tosan (2012) reported that water and water bodies in major part of Nigeria are highly toxic due to the release of waste into them by industries and the oil exploration, spillage and dredging of oil companies. The polluted nature of water and viable water bodies make the aquaculture production sector unattractive in these areas, especially in and around the Delta and River states of Nigeria. However, those who still practice aquaculture have to treat the water, especially shared water flows, before they can use it for production. This leads to high production costs to the fish farmer. Lastly, marketing and distribution channels are ineffective in the country. Oluwatayo and Adedeji (2019) noted that the transportation system for fish and fish products to be made available to markets (consumers) is bad, as output goes wasted in most cases. Due to the perishability of fish, the few that gets to the market sometimes becomes unsold or sold at a lower price, since consumers are not willing to pay a high price for produce that are near their shelf live. This makes the business of producing and venturing into aquaculture difficult and unattractive to the productive hands, farmers and investors in Nigeria.

Other challenges identified by other authors include the shortage of inputs (fingerlings and feed), lack of knowledge resulting in poor management practices, inadequate funding, theft, and direct involvement of government in production (Lam et al., 2012). Use of poor quality seeds, inadequate information, high cost of feeds, traditional techniques, small-size holdings, poor infrastructural facilities, and low capital investment are also factors reported to be limiting the growth of aquaculture sector in Nigeria (Ugwumba \& Chukwuji, 2010; Adewumi, 2015; Adebayo \& Daramola, 2013).

\subsection{COVID-19 and Aquaculture}

Coronavirus disease 2019 popularly known as COVID-19 is caused by severe acute respiratory syndrome coronavirus 2. A similar strain of the virus SARS-CoV-1, which was reported to have affected 8000 people in 2002-2003 (Surico \& Galeotti, 2020). A study in February 2020 revealed that the virus is made of $96 \%$ DNA match between bat coronavirus and human through an intermediate host (Xu et al., 2020). The virus enters through the mouth, eyes, and nose, attaching itself to respiratory tracts through the production of a protein called ACE2. The virus has become a global pandemic with only a handful of countries exempted or without any cases. The actual magnitude of the spread is still unclear as global confirmed cases have already exceeded the 1million mark in less than a year. Although no research has proven that COVID-19 affects fish, it's the human component of aquaculture that raises concern for the sector. In Nigeria, the pandemic is expected to have serious consequences on the country's aquaculture directly and indirectly. Indirectly, Nigeria's underdeveloped health sector will mean an immense pressure on aquaculture. This will imply that the number of the labour force will drop as the infrastructure at the health sector cannot hold the likely number of infected persons. UNDP (2020) reports that the likely fall in labour will lead to a serious economic and fiscal crisis. GDP growth has already 
fallen to $-1.58 \%$ mainly from oil prices decline by $55 \%$. As the outbreak continues to intensify, the countries services, trade, and financial sectors will fall along with the falling GDP as the sector continues $30 \%$ to GDP.

For the aquaculture sector, this will mean that farms are likely to lose their workforces especially commercial farms that need a larger number of labour. This will also mean that farms will have to reduce their production capacity to hold the available workforce. Marketing of the end product of fish farming (fish at all stages of growth) cannot be done as the country has adopted policies of lockdown, the ban on interstate travel, and also a ban on import and export. With this means restricting marketing, it expected that sales volume will fall greatly as market sizes will be reduced to the local market. This may be good for small farms in the short run but in the long run, be overshadowed by big ones. On consumption, it's expected that the fall in production level will mean price increase to help cushion losses made by farmers. Directly, the sector faces huge competition from other protein sources as the relative cost of other protein source are likely to be low to fish. It will be expected that the consumption pattern of consumers will shift to a cheaper source.

\section{Materials and Methods}

\subsection{Description of the Study Area}

Oyo state is an inland state, which is located in the southwestern part of Nigeria with its capital being Ibadan. The state is located on longitude $8^{\circ} 10^{\prime} \mathrm{N}$ and Latitude $4^{\circ} 15^{\prime} \mathrm{E}$. The state was created in 1976 from the western state which included Osun sate until it was spilled in 1991 (Makinde, 2014). The state is home to the Yoruba ethnic group, who are predominately agrarian. The state is bounded by Osun state (east), Ogun state (South and partly to the west), Kwara state (North). In 2006, the state had a total population of 5,580,894 (National Population Commission, 2006). The state covers an estimated land size of 10,986 sq. mi (28,454 square km) making it the $14^{\text {th }}$ biggest state in the country (Umeokeke, Okoruwa, \& Adeyemo, 2017). Its landscape is mostly made of old hard rocks and dome-shaped hills rising gently from 500 meters in the southern part to 1200 meters in the northern part of the state. The state has its climate being equatorial with dry (starting from November to March) and wet season (April to October) with relatively high humidity. The temperature of the state range between $25{ }^{\circ} \mathrm{C}$ and $35^{\circ} \mathrm{C}$ yearly (Adeogun et al., 2017). The nature of the climate favours the development of fishing and fish farming activities as while as the growth of food crops and cash crops such as yam, maize, cassava, plantain, millet, rice, and banana.

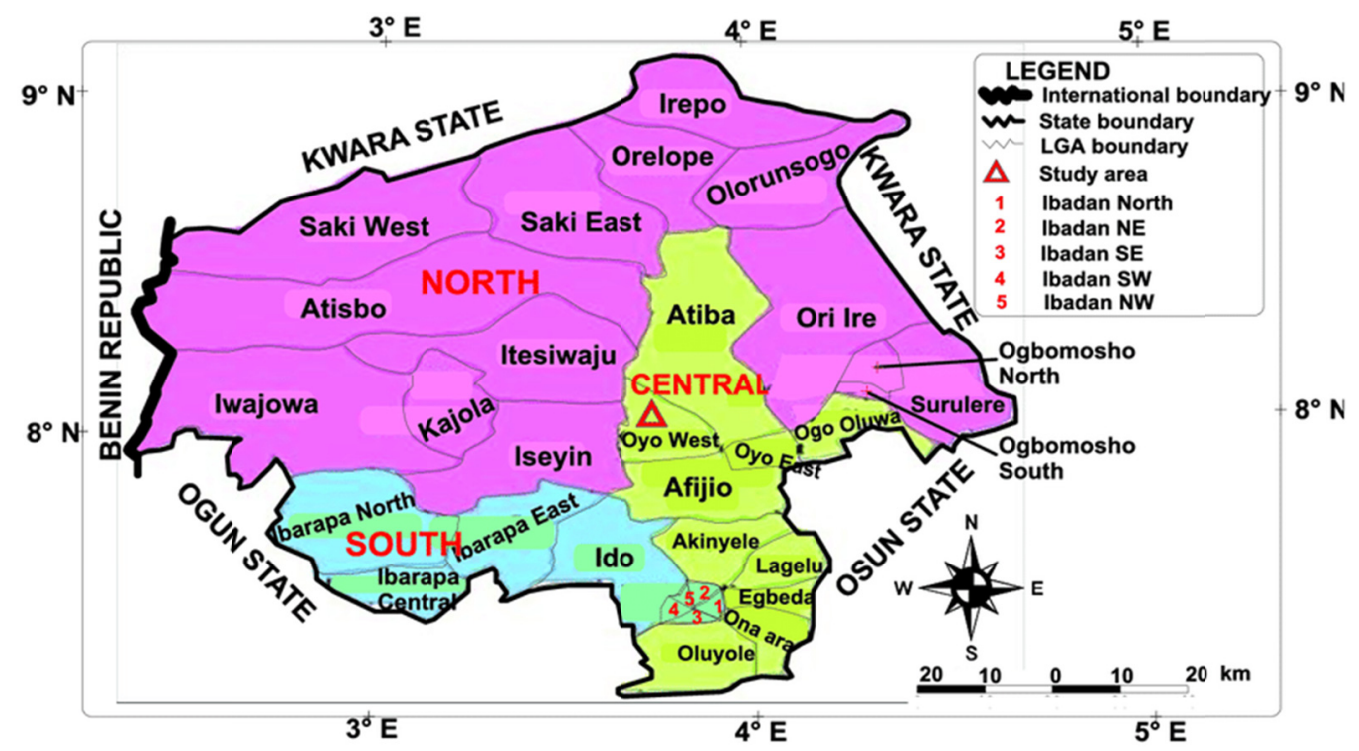

Figure 1. A map of Oyo state (Adopted from Adagunodo et al., 2018)

\subsection{Research Design}

The study adopted the cross sectional survey design. The cross sectional survey design was adopted to helps measure the outcome and the exposure of respondents (fish farmers) to the effect of COVID-19 on their activities within the period of the virus. This allows for generalization of the study to a large population-based on inference from the sample. The selection of respondents for the study was based on the respondent being in 
Nigeria and a fish farmer. The advantage of this design is that it allows for the study to be conducted relatively faster and it is inexpensive.

\subsection{Sample Procedure and Sample Size}

The study used the purposive sampling technique to select fish farmers. Due to the homogenous nature of fish farming activities in Nigeria, the studies made use of the homogenous purposive sampling (Type of purposive sampling). The population of the study was all fish farmers in Nigeria during the period of COVID-19. However, the actual number of the population was unknown. As a general rule, selecting a larger sample size is better than a smaller sample size. This is because the larger the sample size the smaller the sampling error and the higher the representativeness of the sample to the population. The intended sample size of the study was obtained using Slovin's formula (1960) for the unknown population. The desire sample size for the study was 20 respondent, hence;

$$
\mathrm{n}=\frac{\mathrm{N}}{1+\mathrm{Ne}^{2}}
$$

Where, $\mathrm{N}=$ population size; $\mathrm{e}=$ margin of error; $\mathrm{n}=$ sample size .

However, the unwillingness of the respondent and the difficulties involved in getting respondents to answer the questionnaires made the desire sample size unachievable. At the end of the data collection, a total of 11 respondents answered the questionnaire.

\subsection{Sample Collection Instrument}

Primary data was used for the study, which was obtained through the use of a questionnaire (google form). The selection of primary data was due to the COVID-19 being a new phenomenon and the absence of existing data. Primary data has the advantage of ensuring reliable data is obtained. Face validity and content validity of the instrument was ensured through a review of an expert to remove ambiguous and misleading questions. The questionnaire was made up of both open and close-ended questions. The questionnaire was made up of four parts, namely:

(1) Socioeconomic characteristics: This looked at the socioeconomic characteristics of respondents in terms of age, educational qualification, sex, farm size and the number of ponds used, number of smoking kink, number of nurseries tanks, and COVID-19 status of the farm. Socioeconomic characteristics were included to find out the basic characteristics of fish farmers. This was meant to find out if these characteristics have any influence on the perception, challenge, and measures adopted by the respondent.

(2) Perception of fish farmers about COVID-19: This looked at how respondents perceived the effect of COVID-19 on their activities. This was mostly made up of questions looking at the agreement level of respondents on the perceived effect COVID-19 is having on their activities.

(3) Challenges of aquaculture caused by COVID-19: This section looked at the challenges faced by the respondent during COVID-19. This section of the questionnaire provided possible challenges likely to be faced by farmers from literature and also opportunity was made for them to add their challenges which were not captured.

(4) Measures adopted to reduce the effect of COVID-19: This section of the questionnaire looked at measures adopted by respondents to reduce the effect of the pandemic on the aquaculture. Respondents were provided some basic mitigation strategies and asked if applied and also provided the opportunity for them to mention their mitigation strategies adopted.

\subsection{Data Analysis Techniques}

Collected data was converted into Excel version 2013 for cleaning and adjusted per the protocol. The data was then transferred into SPSS version 25.0 for analysis. The analysis was based on the objectives of the studies. The analytical tools for each of the objectives are:

(1) Socioeconomic characteristics: The socioeconomic characteristics of the respondent were analyzed using descriptive statistics like the frequency, percentage, mean, Standard deviation, and t-test. Descriptive statistics were used to show the distribution of respondents across age, farm size, education, number of ponds, number of nursery tanks, number of smoking kinks, type of species, COVID-19 affected status of farm, and sex.

(2) Perception of fish farmers about COVID-19: Perception of the respondent was analyzed using descriptive statistics like the frequency, and percentage. The frequency and percentages were based on the level of agreement to the perception variables of the study. 
(3) Challenges of aquaculture caused by COVID-19: This was analyzed using the Kendell's coefficient of concordance to rank the challenges caused by COVID-19. The challenge with the highest mean value was the most felt challenge by respondents. A further test was conducted using the Wilcoxon sign rank test to match the challenges. This was essential in calculating the difference in the match (pairs) and also reveal if there existed any significant differences. Bonferroni adjustment was also used to test the comparisons that exist between the challenges. The rule for the Bonferroni adjustment was that the p-value for each test must equal alpha divided by the number of tests.

(4) Measures adopted to reduce the effect of COVID-19: The measures adopted to reduce the effect of COVID-19 were analyzed using a bar chart to give an illustrative representation of which measures were most adopted.

\section{Result}

\subsection{Socioeconomic Characteristics of Respondent}

The results on socioeconomic characteristics of respondents as displayed in table 1 below showed that majority of fish farmers interviewed were aged 25-35 (10) and predominantly were females (8). Females (8) were more likely to engage in fish farming than males (3) despite the labour intensiveness of fish farming.

On the educational level, it was revealed that most of the respondents had tertiary education (6). Farm size under this study was mostly small, measuring $0.5-2.5$ acres (7). 1-15 ponds (2) were used by the majority of the farmers for their activities. 10 of the respondent were using 0-10 nursery tanks and 2 of the total respondent had 0-5 smoking kinks for their operations. The most farmed fish species revealed by table 1, showed that Catfish was leading with 8 respondents

Lastly, the result on COVID-19 affecting farming activities, showed that 10 respondents out of the 11 said "yes" their operations have been affected by COVID-19. 
Table 1. Socioeconomic characteristics of respondent

\begin{tabular}{|c|c|c|c|c|}
\hline Variables & Freq. & $\%$ & Mean \pm SD & $\mathbf{t}$ \\
\hline Age & & & $1.091 \pm .302$ & $12.000 * * *$ \\
\hline $25-35$ & 10 & 90.9 & & \\
\hline $46-56$ & 1 & 9.1 & & \\
\hline \multicolumn{5}{|l|}{ Sex } \\
\hline Male & 3 & 27.3 & & \\
\hline Female & 8 & 72.7 & & \\
\hline Education & & & $3.273 \pm 1.009$ & $10.757 * * *$ \\
\hline No formal Education & 1 & 9.1 & & \\
\hline Primary & 1 & 9.1 & & \\
\hline Secondary & 3 & 27.3 & & \\
\hline Tertiary & 6 & 54.5 & & \\
\hline Farm size & & & $1.455 \pm .688$ & $7.016^{* * *}$ \\
\hline $0.5-2.5$ & 7 & 63.6 & & \\
\hline $2.6-5.6$ & 3 & 27.3 & & \\
\hline $6.7-10.7$ & 1 & 9.1 & & \\
\hline Number of ponds & & & $1.182 \pm .405$ & $9.690 * * *$ \\
\hline $1-15$ & 9 & 81.8 & & \\
\hline $16-30$ & 2 & 18.2 & & \\
\hline Number of nursery tanks & & & $1.091 \pm .302$ & $12.000^{* * *}$ \\
\hline $0-10$ & 10 & 90.9 & & \\
\hline $11-21$ & 1 & 9.1 & & \\
\hline Number of smoking kinks & & & $1.182 \pm .405$ & $9.690^{* * *}$ \\
\hline $0-5$ & 9 & 81.8 & & \\
\hline $6-11$ & 2 & 18.2 & & \\
\hline Type of species & & & $1.909 \pm .539$ & $11.739 * * *$ \\
\hline Catfish & 8 & 72.7 & & \\
\hline Tilapia & 2 & 18.2 & & \\
\hline Both & 1 & 9.1 & & \\
\hline COVID-19 status of farm & & & $1.182 \pm .603$ & $6.500 * * *$ \\
\hline Yes & 10 & 90.9 & & \\
\hline No & 0 & 0.0 & & \\
\hline Not yet & 1 & 9.1 & & \\
\hline
\end{tabular}

Note. $\mathrm{n}=11 ; * *$ : Significant at $5 \%$.

$\mathrm{H}_{0}$ : There is no significant relationship between the socioeconomic characteristics of the respondent.

The hypothesis of significance between the socioeconomic characteristics of the respondent revealed that there exists no significant relationship between the various variables at $5 \%$ alpha value. Hence, we reject the null hypothesis. This implies that the socioeconomic characteristics of fish farmers played a significant role in the extent of impacted faced during the COVID-19 pandemic.

\subsection{Perception of Fish Farmers on the Influence of COVID-19 on Farming Activities}

The result on the perception of fish farmers on the influence of COVID-19 on their farming activities showed that the pandemic caused a decline in demand (72.7\%), high cost of production (63.6\%), making fish more expensive (54.5\%) and reduction of manpower on the farm due to the lockdown (63.6). However, farmers disagreed that the pandemic led to improve sales volume (63.6\%). On improved marketing strategies (63.6\%) and increase feasibility in the market (45.5\%), it was shown that farmers were indifferent as to the influence of the pandemic. 
Table 2. Perception of fish farmers

\begin{tabular}{llll}
\hline \multirow{2}{*}{ Variables } & \multicolumn{3}{c}{ Response (\%) } \\
\cline { 2 - 4 } & Disagree & Neutral & Agree \\
\hline Demand decline & $2(18.2)$ & $1(9.1)$ & $8(72.7)$ \\
The high cost of production & $1(9.1)$ & $3(27.3)$ & $7(63.6)$ \\
Fish is more expensive & $2(18.2)$ & $3(27.3)$ & $6(54.5)$ \\
Improved marketing strategies & $1(9.1)$ & $7(63.6)$ & $3(27.3)$ \\
Improved sales volume & $7(63.6)$ & $3(27.3)$ & $1(9.1)$ \\
Increase feasibility in the market & $4(36.4)$ & $5(45.5)$ & $2(18.2)$ \\
Reduction of manpower on the farm due to lockdown & $1(9.1)$ & $3(27.3)$ & $7(63.6)$ \\
\hline
\end{tabular}

Note. $\mathrm{n}=11$.

\subsection{Challenges Faced by Fish Farmers During COVID-19}

Table 3, below showed the challenges faced by fish farmers during the period of the COVID-19 pandemic. The results showed that the major challenge faced by fish farmers was the reduction in walk-in customers to the farmers (4.50), this was followed by the high cost of inputs (4.29), inability to access raw materials (4.01), inability to access the fish market because of the lockdown (3.98), inability to access fingerlings (3.84), inability to get technical support (3.73) and the least challenge being employee's inability to come to work because of the lockdown (3.66).

A further probe into the results leads to the Wilcoxon sign rank test to find the relationship that exists between the variables and the significance of the relationship. The pairing of the variables revealed that all the variables had opposite direction, meaning that none of the variables was dependent on the other as shown by the Z-score. A look at the significance level revealed that; Inability to access fingerlings * Reduction in walk-in customers to farm, Inability to access fingerlings * High cost of input, Employees inability to come to work because of the lockdown * Reduction in walk-in customers to farm, Employees inability to come to work because of the lockdown * Inability to access fish market because of the lockdown, Employees inability to come to work because of the lockdown * High cost of inputs, Inability to get technical support * Reduction in walk-in customers to farm, Reduction in walk-in customers to farm * Inability to access fish market and Inability to get technical support * High cost of inputs were observed as significant. However, the Bonferroni adjustment (correction) was used to check for errors that may have occurred. The result of the Bonferroni adjustment showed that only; Employees' inability to come to work because of the lockdown * Reduction in walk-in customers to farm and Inability to get technical support * reduction in walk-in customers to the farm were significant. This implies that the reduction in walk-in customers to the farm, which was the major challenge faced by fish farmers was tied to the employees' inability to come to work because of the lockdown, and the absence of technical support.

Table 3. Kendall Coefficient of Concordance for Challenges faced by fish farmers during COVID-19

\begin{tabular}{lllll}
\hline Challenges faced by fish farmers & Mean & SD & Mean Rank & Median \\
\hline Inability to access fingerlings & 1.50 & .50 & 3.84 & 1.50 \\
Inability to access raw materials & 1.55 & .50 & 4.01 & 2.00 \\
Employees inability to come to work because of the lockdown & 1.45 & 1.45 & 3.66 & 1.00 \\
Reduction in walk-in customers to farm & 1.69 & 1.69 & 4.50 & 2.00 \\
Inability to get technical support & 1.47 & 1.47 & 3.73 & 1.00 \\
Inability to access the fish market because of lockdown & 1.54 & 1.54 & 3.98 & 2.00 \\
The high cost of inputs & 1.63 & 1.63 & 4.29 & 2.00 \\
\hline
\end{tabular}

Note. $\mathrm{n}=11 ; \sigma^{2}=23.714$ Asymp; Sig. $=.001 ;$ Overall Median $=1.50$. 
Table 4. Wilcoxon signed-rank test for challenges faced by fish farmers during COVID-19

\begin{tabular}{|c|c|c|c|}
\hline Challenges faced by fish farmers & Z-score & Sig. & $\begin{array}{l}\text { Bonferroni } \\
\text { Adjustment } \\
(p<.002)\end{array}$ \\
\hline Inability to access fingerlings * Inability to access raw materials & -.674 & .500 & Not significant \\
\hline Inability to access fingerlings * Employees inability to come to work because of the lockdown & -.898 & .369 & Not significant \\
\hline Inability to access fingerlings * Reduction in walk-in customers to farm & -3.042 & $.002 * * *$ & Not significant \\
\hline Inability to access fingerlings * Inability to get technical support & -.600 & .549 & Not significant \\
\hline Inability to access fingerlings * Inability to access fish market because of lockdown & -.649 & .516 & Not significant \\
\hline Inability to access fingerlings * High cost of input & -2.335 & $.020 * * *$ & Not significant \\
\hline Inability to access raw materials * Employees inability to come to work because of the lockdown & -1.508 & .132 & Not significant \\
\hline Inability to access raw materials $*$ Reduction in walk-in customers to farm & -1.941 & .052 & Not significant \\
\hline Inability to access raw materials * Inability to get technical support & -1.109 & .267 & Not significant \\
\hline Inability to access raw materials * Inability to access fish market because of lockdown & -.135 & .893 & Not significant \\
\hline Inability to access raw materials * High cost of input & -1.206 & .228 & Not significant \\
\hline Employees inability to come to work because of the lockdown * Reduction in walk-in customers to farm & -3.618 & $.000 * * *$ & Significant \\
\hline Employees inability to come to work because of the lockdown * Inability to get technical support & -.535 & .593 & Not significant \\
\hline Employees inability to come to work because of the lockdown * Inability to access fish market because of the lockdown & -2.714 & $.007 * * *$ & Not significant \\
\hline Employees inability to come to work because of the lockdown * High cost of inputs & -3.087 & $.002 * * *$ & Not significant \\
\hline Inability to get technical support $*$ Reduction in walk-in customers to farm & -3.395 & $.001 * * *$ & Significant \\
\hline Reduction in walk-in customers to farm * Inability to access fish market & -2.023 & $.043 * * *$ & Not significant \\
\hline Reduction in walk-in customers to farm $*$ High cost of input & -1.095 & .273 & Not significant \\
\hline Inability to get technical support * Inability to access fish market because of lockdown & -1.400 & .162 & Not significant \\
\hline Inability to get technical support $*$ High cost of inputs & -2.921 & $.003 * * *$ & Not significant \\
\hline inability to access fish market because of lockdown * High cost of input & -1.342 & .180 & Not significant \\
\hline
\end{tabular}

Note. $\mathrm{n}=11 ; * * * \mathrm{p}<0.05$.

$\mathrm{H}_{1}$ : The paired challenges faced by farmers during COVID-19 are not different.

The test of the paring for the challenges faced by fish farmers during the COID-19 revealed that not all the pairing were significant, hence, the null hypothesis of "The paired challenges faced by farmers during COVID-19 are not different" was accepted, implying that the challenges faced by fish farmers were not paired in occurrence, but rather a sequential occurrence (one challenge leads to another).

\subsection{Coping Strategies Adopted to Mitigate the Effect of COVID-19}

The coping strategies adopted to mitigate the effect of COVID-19 by fish farmers is shown in Figure 2. The results revealed that the most adopted strategy was the development of own feed (36.4\%), this was followed by reduction in borrowing rate (27.3\%), assistance from the government and organisations (18.2\%) while, the least adopted was the reduction in production activities and starving fish for days $(9.1 \%)$. 


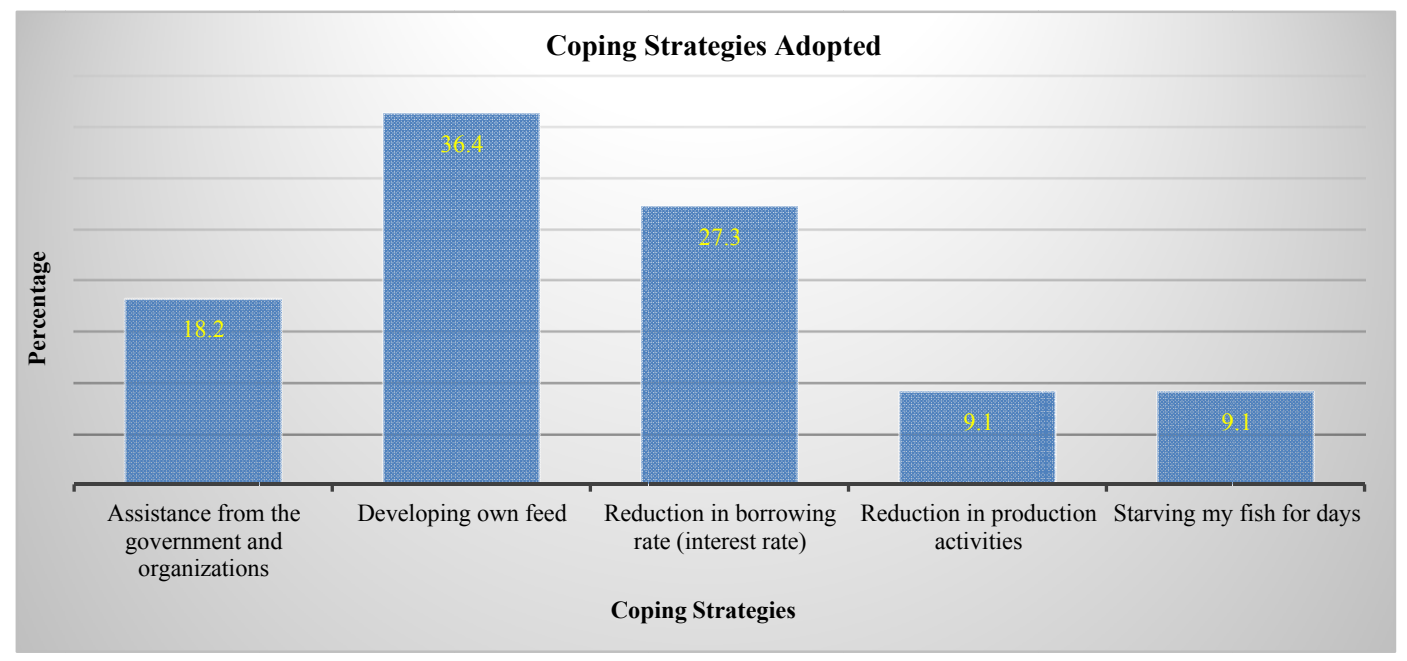

Figure 2. Coping Strategies adopted to mitigate the effect of COVID-1

\section{Discussion}

\subsection{Socioeconomic Characteristics of Respondent}

On age, the result found agrees with Pandey and Upadhayay (2012) and Salau et al. (2014) who found out that young people are more likely to engage in fish farming than older people due to the labour and capital intensive of fish farming. Whiles with gender, the results was inconsistent with Ifejika et al. (2018) and Olaoye et al. (2016) whose findings revealed that males are more likely to engage in fish farming activities due to the labour intensity. The hypothetical reason for our findings being at variance could be due to males taking the risk during the lockdown to find alternative income and food source to supplement the already depleted household income and food. Hence females are left with the responsibility of taking care of the fish farms.

Results on education is consistent with Olaoye et al. (2016) who found out that fish farmers were well educated and had obtained tertiary education. The results of Pandey and Upadhayay (2012) were consistent with findings of this research, which found out that fish farmers were mostly small in nature due to the issue of land litigation, low capital of farmers and subsistence nature of production.

The result on nursery tanks agrees with Abraham, Sil, and Vineetha (2010), who reported that fish farmers have less number of nursery tanks because of their small scale nature of operation. Olaoye et al. (2016) findings on smoking kinks number is consistent with this research, which revealed that farmers have low number (0-5) of smoking kinks because of the small nature of their production capacity and the high demand for fresh fish over smoked.

The result of this research is consistent with Adeoye and Elegunde (2012), who in their research reported that Nigeria's aquaculture sector is monoculture in nature, with catfish being the most farmed fish species. This agrees with Senten et al. (2020) studies in the US, which revealed that $90 \%$ of 537 fish farmers accepted that COVID-19 has affected their farm activities.

\subsection{Perception of Fish Farmers on the Influence of COVID-19 on Farming Activities}

The results agrees with Sunny et al. (2020) and Senten et al. (2020), which revealed that fish farmer's perception on COVID-19 has led lead to a reduction in their income due to the high cost of production, and decline in demand. This implies that the impact of COVID-19 on aquaculture was felt from both the demand and supply side. Also, the result implies that government policies like the inner state lockdown had negative impact on aquaculture in Oyo state. As cost of production increased within the period, input price rose and consumer restricted movement reduced demand for fish and fish products in the state.

\subsection{Challenges Faced by Fish Farmers During COVID-19}

The findings disagreed with Sunny et al. (2020), whose report showed that the major challenge faced by fish farmers was the low attendance of service providers. Morgan et al. (2017) noted that the disruption of the production process lead to a large failure of farms attaining profitability status.This implies that the major challenge to fish farming during the COVID-19 period was market for input and output, which could be attributed to the restriction on movement within the country. Also, Adebayo and Daramola (2013) and Lam et al. 
(2012), revealed that Nigerian aquaculture sector, before the pandemic, was already faced with challenges such as the shortage of inputs (fingerlings and feed), lack of knowledge resulting in poor management practices, inadequate funding, use of poor quality seeds, direct involvement of government in production,inadequate information, high cost of feeds, traditional techniques, small-size holdings poor infrastructural facilities, and low capital investment. This implies that COVID-19 pandemic was not the actual cause of challenges faced by farmers, but they are already exposed to these challenges. Consultative Group on International Agricultural Research (CGIAR,2020) and the fisheries committee for the West Central Gulf of Guinea (FCWC, 2020) also reported that the major challenges of Nigeria aquaculture during the COVID-19 period was the decline in demand, inability to access to market (input and output markets), reduced technical assistance to far and high cost of production. It further reported that the difficulties faced by fish farmers is rooted in the government policy of movement restriction (Movement control order (MCO).

\subsection{Coping Strategies Adopted to Mitigate the Effect of COVID-19}

The result on development of own feed is consistent with van Beijnen and Yan (2020), who in their research reported that African fish farmers should focus on the production of their own product (input) to reduce the cost of production. Fish farmer's adaptation of developing their own feed could be attributed to the high cost of input and the restriction on movement, which hindered access to the input market. An FAO (2020) report in April, 2020 emphasised the need of governments to support the aquaculture sector through subsidies and other relief services. This support the finding of this study that assistance from government and stakeholders and the reduction of borrowing rate are principal coping strategies adopted by the Nigerian aquaculture sector.

\section{Conclusion}

The global health crisis caused by COVID-19 has led to an unexpected effect on world economies with economies struggling to mitigate the effect of the pandemic. The Nigerian aquaculture sector is no exception to these difficulties. The pandemic has led to increased cost of input, raw material, market inaccessibility and the reduction of walk-in customers to farms. This is as a result of some policies taken by the government, like measures restricting movement and the closure of the country's borders.

This study was conducted to find out the extent of the impact of COVID-19 on the Nigeria aquaculture, and the adaptation strategies farmers are undertaking to mitigate it impact. The study's core objective was to identify the socioeconomic characteristics of fish farmers in Nigeria, examine the perception of fish farmers on the influence of COVID-19 on aquaculture, identify challenges faced by fish farmers during COVID-19 and coping strategies adopted to mitigate the impact of COVID-19 in the sector. The study found that there is significant difference in the relationship between socioeconomic characteristics of fish farmers. It also revealed that fish farmers perceived that COVID-19 has led to the decline in the demand of fish purchase. Cost of fish input has increased and a reduction of manpower on the farm due to the lockdown protocol were further observed. Farmers also revealed that the cost of fish is more expensive during the COVID-19 period.

Furthermore, the study revealed that the major challenge faced by fish farmers during the COVID-19 period was the reduction in walk-in customers to the farmers. This has made farmers to develop their own feed and also taking advantage of the government reduced interest rate policy to reduce the impact on their activities.

The study therefore concludes that fish farming and its related activities are submerged in various degrees of shocks. These shocks are either from within the aquaculture sector or spill-overs from national shocks from to the emergence of the COVID-19 pandemic. Hence government and stakeholders in reducing such shocks, should consider a holistic approach to national policies on aquaculture.

\section{Recommendation}

The study recommends that fish farmers and other stakeholders engaged in aquaculture in Nigeria should begin considering multiple supply chains for aquaculture products in an attempt to reduce shocks such as those exposed by COVID-19.

Fish farmers should also consider other marketing approaches like online marketing and contract farming to create direct market avenues for their products.

The government and private sector stakeholders in aquaculture in Nigeria should invest in the local production of fish feed and other fish farming inputs to reduce the cost of fish farming and also create lucrative jobs in the sector.

Lastly, the government of Nigeria should continue with it reduced lending rate and subsidies to cushion fish farmers entering into the post-COVID-19 fish farming season. 


\section{Acknowledgment}

We wish to thank the Department of Fisheries and Aquaculture, University of Ibadan for their support throughout the research process.

\section{Reference}

Abraham, T. J., Sil, S. K., \& Vineetha, P. (2010). A comparative study of the aquaculture practices adopted by fish farmers in Andhra Pradesh and West Bengal. Indian Journal of Fisheries, 57(3), 41-48.

Adagunodo, T. A., Sunmonu, L. A., Oladejo, O. P., Hammed, O. S., Oyeyemi, K. D., \& Kayode, O. T. (2018). Site characterization of Ayetoro housing scheme, Oyo, Nigeria. In IOP Conference Series: Earth and Environmental Science, 173(1), 12-31. https://doi.org/10.1088/17551315/173/1/012031

Adebayo, O. O., \& Daramola, O. A. (2013). Economic analysis of catfish (Clarias gariepinus) production in Ibadan metropolis. Journal of Agriculture and Food Sciences, 1(7), 128-134. Retrieved from http://www.resjournals.org/JAFS

Adeogun, A. O., Popoola, K. O., Oduola, A. O., Olakiigbe, A. K., \& Awolola, S. T. (2017). High level of DDT resistance and reduced susceptibility to deltamethrin in Anopheles gambiae, Anopheles coluzzi, and Anopheles arabiensis from Urban Communities in Oyo State, South-West Nigeria. Journal of Mosquito Research, 7(16), 125-133. https://doi.org/10.5376/jmr.2017.07.0016

Adeoye, A. O., \& Elegunde, A. F. (2012). Impacts of external business environment on organizational performance in the food and beverage industry in Nigeria. British Journal of Arts and Social Sciences, 6(2), 194-201. Retrieved from http://www.bjournal.co.uk/BJASS.aspx

Adewumi, A. A. (2015). Aquaculture in Nigeria: Sustainability issues and challenges. Direct Resource Journal of Agriculture and Food Science, 3(12), 223-231. Retrieved from https://directresearchpublisher.org/drjafs/ abstract/aquaculture-in-nigeria-sustainability-issues-and-challenges

Akinrotimi, O. A., Abu, O. M. G., \& Aranyo, A. A. (2011). Environmental friendly aquaculture key to sustainable fish farming development in Nigeria. Continental Journal of Fisheries and Aquatic Science, 5(2), 17-31. Retrieved from http://hdl.handle.net/1834/24296

Brugère, C., Aguilar-Manjarrez, J., Beveridge, M. C., \& Soto, D. (2019). The ecosystem approach to aquaculture 10 years on a critical review and consideration of its future role in blue growth. Reviews in Aquaculture, 11(3), 493-514. https://doi.org/10.1111/raq.12242

Cai, J., \& Leung, P. (2017). Short-term projection of global fish demand and supply gaps. Rome, Italy: FAO.

Chinese Center for Disease Control and Prevention. (2020). Distribution of new coronavirus pneumonia. Retrieved July 20, 2020, from http://2019ncov.chinacdc.cn/2019-nCoV

Cisneros-Montemayor, A. M., \& Vincent, A. C. (2016). Science, society, and flagship species: Social and political history as keys to conservation outcomes in the Gulf of California. Ecology and Society, 21(2). https://doi.org/10.5751/ES-08255-210209

Consultative Group on International Agricultural Research. (2020). WorldFish discussed COVID-19 impact with Nigerian aquaculture community. Retrieved from https://fish.cgiar.org/news-and-updates/news/worldfishdiscussed-covid-19-impacts-nigerian-aquaculture-community

Eriegha, O. J., \& Ekokotu, P. A. (2017). Factors affecting feed intake in cultured fish species: A review. Animal Research International, 14(2), 2697-2709.

Famakinwa, M., Agboola, A. F., Alabi, D. L., \& Ogunjimi, S. I. (2017). Factors Associated with Land Accessibility among Rural Dwellers in Osun State, Nigeria. Middle-East Journal of Scientific Research, 25(3), 528-535. https://doi.org/10.5829/idosi.mejsr.2017.528.535

FAO. (2009). Aquaculture (Technical Paper, No. 523). Rome, Italy: UNEP/FAO.

FAO. (2020). How is COVID-19 affecting the fisheries and aquaculture food systems. Rome, Italy: FAO.

Fisheries Committee for the West Central Gulf of Guinea. (2020). Nigeria: Addressing impact of COVID-19 on fish. Retrieved from https://fcwc-fish.org/other-news/nigeria-addressing-impact-of-covid-19-on-fish

Gilbert, S. M., \& Gubar, S. (2020). The madwoman in the attic: The woman writer and the nineteenth-century literary imagination. Connecticut, USA: Yale University Press. https://doi.org/10.2307/j.ctvxkn74x 
Grema, H. A., Jacob, K., Mohammed, B., \& Umaru, O. H. (2020). Understanding Fish Production and Marketing Systems in North-western Nigeria and Identification of Potential Food safety Risks Using Value Chain Framework. Preventive Veterinary Medicine, 181(105038), 1-30. https://doi.org/10.1016/j.prevetmed. 2020.105038

Haldén, A. N., Lindberg, J. E., \& Masembe, C. (2014). Aquaculture-A fast growing food production sector. SLU Glob, 4(1), 42-45.

Ifejika, P. I., Akinbile, L. A., Ifejika, L. I., \& Olajide, J. O. (2018). The Socio-economic effects on adoption of aquaculture technology among fish farmers in anambra state, Nigeria. Journal of Agricultural Extension, 11(01), 74-86.

Kawarazuka, N. (2010). The contribution of fish intake, aquaculture, and small-scale fisheries to improving nutrition: a literature review (The WorldFish Center Working Paper No. 2106). Penang, Malaysia: The WorldFish Center.

Lam, V. W., Cheung, W. W., Swartz, W., \& Sumaila, U. R. (2012). Climate change impacts on fisheries in West Africa: Implications for economic, food and nutritional security. African Journal of Marine Science, 34(1), 103-117. https://doi.org/10.2989/1814232X.2012.673294

Makinde, A. F. K. (2014). 4 The Evolution of the Independent sharía Panel in Osun State, South-West Nigeria. Sharīa in Africa Today, 15(1), 71-101. https://doi.org/10.1163/9789004262126_005

Morgan, M., Terry, G., Rajaratnam, S., \& Pant, J. (2017). Socio-cultural dynamics shaping the potential of aquaculture to deliver development outcomes. Reviews in Aquaculture, 9(4), 317-325. https://doi.org/ 10.1111/raq. 12137

National Population Commission. (2006). The Nigeria Population Census 2006. Lagos, Nigeria: National Bureau of Statistics.

Nchuchuwe, F. F., \& Adejuwon, K. D. (2012). The challenges of agriculture and rural development in Africa: the case of Nigeria. International Journal of Academic Research in Progressive Education and Development, $1(3), 45-61$.

Olaoye, O. J., Ezeri, G. N. O., Akegbejo-Samsons, Y., Awotunde, J. M., \& Ojebiyi, W. G. (2016). Dynamics of the adoption of improved aquaculture technologies among fish farmers in Lagos State, Nigeria. Croatian Journal of Fisheries, 74(2), 56-70. https://doi.org/10.1515/cjf-2016-0012

Olowosegun, O. M., Olowosegun, T., \& Mohammed, H. (2005). A review on the effect of water pollution onfish and the fishing industry of Nigeria. 2005 FISON Conference Proceedings. Port Harcourt, Nigeria: FISON.

Oluwatayo, I. B., \& Adedeji, T. A. (2019). Comparative analysis of technical efficiency of catfish farms using different technologies in Lagos State, Nigeria: A Data Envelopment Analysis (DEA) approach. Agriculture \& Food Security, 8(1), 1-9. https://doi.org/10.1186/s40066-019-0252-2

Omitoyin, S. A., \& Tosan, F. B. (2012). Potential impacts of climate change on livelihood and food security of Artisanal Fisherfolks in Lagos State, Nigeria. Journal of Agricultural Science, 4(9), 20-30. https://doi.org/ $10.5539 /$ jas.v4n9p20

Pandey, D. K., \& Upadhayay, A. D. (2012). Socio-economic profile of fish farmers of an adopted model aquaculture village: Kulubari, West Tripura. Indian Research Journal of Extension Education, 2(1), 55-58.

Pauly, D., \& Zeller, D. (2017). Comments on FAOs state of world fisheries and aquaculture (SOFIA 2016). Marine Policy, 77, 176-181. https://doi.org/10.1016/j.marpol.2017.01.006

Salau, E. S., Lawee, A. Y., Luka, G. E., \& Bello, D. (2014). Adoption of improved fisheries technologies by fish farmers in southern agricultural zone of Nasarawa State, Nigeria. Journal of Agricultural Extension and Rural Development, 6(11), 339-346. https://doi.org/10.5897/JAERD13.0565

Senten, J., Smith, M. A., \& Engle, C. R. (2020). Impacts of COVID-19 on US aquaculture, aquaponics, and allied businesses. Journal of the World Aquaculture Society, 51(3), 574-591. https://doi.org/10.1111/jwas. 12715

Sharma, S., Zhang, M., Gao, J., Zhang, H., \& Kota, S. H. (2020). Effect of restricted emissions during COVID-19 on air quality in India. Science of the Total Environment, 728(1), 138-878. https://doi.org/ 10.1016/j.scitotenv.2020.138878 
Slovin, E. (1960). Slovin's formula for sampling technique. Retrieved from https://scholar.google.com/ scholar?cites $=6349259448973063440 \&$ as_sdt $=2005$ sciodt $=0,5 \& \mathrm{hl}=\mathrm{en}$

Sunny, A. R., Sazzad, S. A., Datta, G. C., Sarker, A. K., Ashrafuzzaman, M., \& Prodhan, S. H. (2020). Assessing Impacts of COVID-19 on Aquatic Food System and Small Scale Fisheries in Bangladesh. Preprints. https://doi.org/10.20944/preprints202006.0143.v1

Surico, P., \& Galeotti, A. (2020). The economics of a pandemic: The case of Covid 19. Wheeler Institute for Business and Development, London Business School, London.

Ugwumba, C. O. A., \& Chukwuji, C. O. (2010). The economics of catfish production in Anambra State, Nigeria: A profit function approach. Journal of Agriculture and Social Sciences, 6(4), 105-109. Retrieved from https://diana.shuu.cf/url?sa=t\&rct=j\&q=\&esrc=s\&source=web\&cd=\&ved=2ahUKEwiAzfDd3rrzAhVyOX0 KHVjTB4EQFnoECAQQAQ\&url=http\%3A\%2F\%2Fwww.fspublishers.org\%2Fpublished papers\%2F715 07_..pdf\&usg=AOvVaw2n0IBhXaD-dj1Ak2N9_4Vo

Umeokeke, N. I., Okoruwa, V. O., \& Adeyemo, T. A. (2017). Impact of electronic-wallet system on farmer's welfare in Oyo State, Nigeria. International Journal of Social Economics, 44(4), 474-490. https://doi.org/ 10.1108/IJSE-07-2015-0184

United Nation Development Programmme. (2020). COVID-19: Looming crisis in developing countries threatens to devastate economies and ramp up inequality. New York, USA: UNDP.

van Beijnen, J., \& Yan, G. (2020). Five ways for fish farmers to survive Covid 19. The Fish Site. Retrieved from https://thefishsite.com/articles/five-ways for-fish farmers-to survive-covid-19

Van der Merwe, M. (2015). Integrating aquaculture with crop systems: An aquaponic enterprise project proposal for the Ntinga Multipurpose Co-operative in Philippi, South Africa (Doctoral dissertation, Stellenbosch University, Stellenbosch).

World Health Organization. (2020). WHO Director-General's remarks at the media briefing on 2019-nCoV on 11 February 2020. Geneva: WHO.

Wu, C., Chen, X., Cai, Y., Zhou, X., Xu, S., Huang, H., \& Song, J. (2020). Risk factors associated with acute respiratory distress syndrome and death in patients with coronavirus disease 2019 pneumonia in Wuhan, China. JAMA Internal Medicine, 180(7), 934-943. https://doi.org/10.1001/jamainternmed.2020.0994

Xu, J., Zhao, S., Teng, T., Abdalla, A. E., Zhu, W., Xie, L., \& Guo, X. (2020). Systematic comparison of two animal-to-human transmitted human coronaviruses: SARS CoV-2 and SARS-CoV. Viruses, 12(2), 244-261. https://doi.org/10.3390/v12020244

\section{Copyrights}

Copyright for this article is retained by the author(s), with first publication rights granted to the journal.

This is an open-access article distributed under the terms and conditions of the Creative Commons Attribution license (http://creativecommons.org/licenses/by/4.0/). 